\title{
Involvement of the transepithelial calcium transport disruption and the formation of epididymal stones in roosters
}

\author{
André Gustavo Oliveira, Diêgo Junior Queiroga Aquino, Germán Arturo Bohórquez Mahecha and \\ Cleida Aparecida Oliveira \\ Department of Morphology, Universidade Federal de Minas Gerais (UFMG), Avenida Antônio Carlos, 6627, 31270 - \\ 901 Belo Horizonte, Minas Gerais, Brazil \\ Correspondence should be addressed to C A Oliveira; Email: cleida@icb.ufmg.br
}

\begin{abstract}
Epididymal lithiasis is a dysfunction of unknown origin characterized by the formation of calcium stones into the lumen of efferent ductules of roosters. Affected animals present an imbalance in the hormonal responsive systems that regulate the expression of proteins involved in the transepithelial calcium transport, as TRPV6, CaBP-D28K, NCX1, and PMCA. Because the efferent ductules are the major site of fluid and calcium reabsorption in excurrent ducts, it was hypothesized that impairment in local calcium homeostasis would lead to lithiasis. To test this hypothesis, we addressed the expression of these proteins in the epididymal region of affected animals. The present study focused on the investigation of the occurrence, tissue distribution, and physiological impact of the transepithelial calcium transport in roosters under normal and pathological conditions. The results showed that affected roosters presented a significant increase in TRPV6 and CaBP-D28k levels, whereas NCX1 and PMCA were not changed. Such alterations were more conspicuous in the proximal efferent ductules, in which was also observed accumulation of calcium within the epithelial cells. These findings provided the first evidences for the involvement of alteration in the expression of proteins essential for calcium reabsorption as a plausible mechanism for the formation of calcium stones within efferent ductules.
\end{abstract}

Reproduction (2012) 143 835-844

\section{Introduction}

The epididymal region of roosters is located at the dorsomedial surface of the testis, being composed by the rete testis, efferent ductules, connecting ducts, and epididymal duct (King 1975, Aire 1979a, 2000, Oliveira \& Oliveira 2011). Among these components, the efferent ductules are the most conspicuous segment as they compose about $25-60 \%$ of the epididymal region (Aire 1979b, Clulow \& Jones 1988, Oliveira et al. 2011b). The efferent ductules of birds are involved in the reabsorption of the bulk of testicular fluid as well as calcium (Clulow \& Jones 1988, 2004) and are considered to play important roles in the maintenance of fertility. Therefore, alterations in the functions of these ductules may negatively impact the reproductive success of roosters.

In this regard, the epididymal lithiasis is a reproductive dysfunction located in the epididymal region of roosters, which is characterized by the formation of abundant luminal calcium stones (Janssen et al. 2000, Mahecha et al. 2002). It has been consensual in the literature related to the epididymal lithiasis that the efferent ductules are the segment most affected by this anomaly, as calcium stones are formed and located in the lumen of the ductules, that also show more drastic morphological alterations (Janssen et al. 2000, Mahecha et al. 2002, Boltz et al. 2004, 2006, Jackson et al. 2006, Oliveira et al. 2008, 2011b). Although the primary cause of epididymal lithiasis is not yet elucidated, considering that: 1) calcium is the major component of the stones; and 2) the efferent ductules are major site for calcium reabsorption in the epididymal region, it has been hypothesized that an imbalance in local calcium homeostasis may be involved in the formation of the luminal calcium stones (Oliveira et al. 2008, 2011b, Oliveira \& Oliveira 2011).

Calcium transport across the epithelium may occur by the movement of the ion between the intercellular spaces - the paracellular pathway - or throughout the epithelial cell cytoplasm - the transepithelial pathway. The transepithelial calcium reabsorption depends on proteins that mediate the apical calcium entry within the cell, named TRPV5 and TRPV6 (transient receptor potential vanilloid channel), the diffusion of the ion throughout the cytoplasm bound to calcium-binding proteins (CaBP), such as CaBP-D9K or CaBP-D28K, and its extrusion to the extracellular environment in the basolateral membranes of the cells by the $\mathrm{Na}^{+} / \mathrm{Ca}^{2+}$ exchanger (NCX) or the plasma membrane 
calmodulin-dependent calcium ATPase (PMCA; Bindels et al. 1991, Van Baal et al. 1996, Hoenderop et al. 2002, 2005, Bar 2009). This process is orchestrated by several hormones that regulate the expression and activity of the aforementioned proteins, including vitamin D3, androgens, and estrogens (Cai et al. 1993, Hoenderop et al. 2001, 2002, 2005, Van Abel et al. 2002, Dick et al. 2003, Meyer et al. 2007, Oz et al. 2007, Suzuki et al. 2008, Hsu et al. 2010, Yang et al. 2011).

Interestingly, the efferent ductules of roosters express high levels of vitamin D3 receptor (VDR), androgen receptor (AR), and estrogen receptors (ESR1 and ESR2 also known as $E R \alpha$ and $E R \beta$ respectively; Kwon et al. 1997, Dornas et al. 2007, 2008, Oliveira et al. 2011a). Roosters affected by epididymal lithiasis expressed significantly higher levels of VDR and ESR2 in the efferent ductules, whereas AR and ESR1 proteins were not altered (Oliveira et al. 2008, 2011b). Moreover, it was shown that affected animals also present alterations in the concentration profiles of hormones that bind to these receptors, as in the epididymal region of these animals estradiol $\left(E_{2}\right)$ levels were increased whereas vitamin D3 and testosterone concentrations were decreased (Oliveira et al. 2011b).

Therefore, based on these information and considering that the responsive systems of hormones that are essential for the maintenance of calcium homeostasis are altered in the epididymal region of roosters, the present study aimed to investigate the expression of TRPV6, CaBP-D28K, NCX1, and PMCA that directly mediate calcium transport across the epithelium, to further elucidate the cause of calcium stones formation within the lumen of efferent ductules. We focused on investigating TRPV6 and CaBP-D28K, instead of TRPV5 and CaBP-D9K respectively, because the former have been previously identified in the reproductive system,
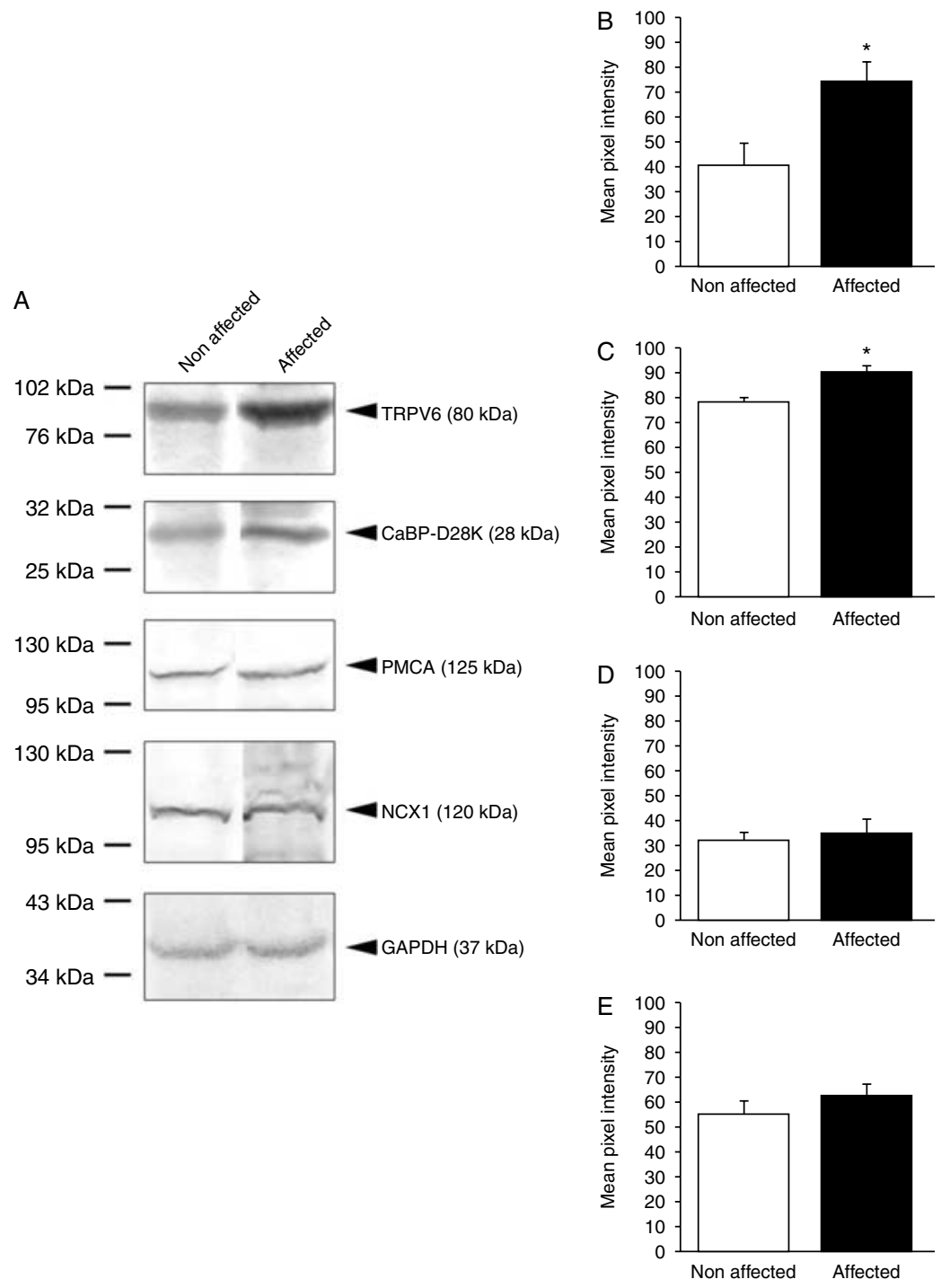

Figure 1 Western blotting analysis of TRPV6, CaBPD28K, PMCA, and NCX1 (A) within the epididymal region of roosters nonaffected and affected by epididymal lithiasis. GAPDH was used as a reference protein. Graphical representation of the image analysis of TRPV6, CaBP-D28K, PMCA, and NCX1 expression (B, C, D and E respectively). $n=5 ; * P \leq 0.05$. 
including bird tissues (den Dekker et al. 2003, Jelinsky et al. 2007, Bar 2008, 2009). In addition, CaBP-D9K has not been detected in bird tissues (Bar 2008, 2009).

\section{Results}

Western blotting assays of the total protein extract of the epididymal region of roosters showed major protein bands of 81, 28, 125, and $120 \mathrm{kDa}$ for TRPV6, CaBPD28K, PMCA, and NCX1 respectively (Fig. 1A). These molecular weights are in agreement with those previously reported in the literature (de Talamoni et al. 1993, Hsu et al. 2010, Kennedy et al. 2010). When compared with nonaffected animals, roosters with epididymal lithiasis presented altered expression of the calcium transporting proteins. The TRPV6 expression within the epididymal region of roosters affected by epididymal lithiasis increased significantly (75\%), whereas CaBP-D28K levels were increased in $13 \%$ (Fig. 1A, B and C). On the other hand, no differences in PMCA and NCX1 expression were found in the epididymal region of affected animals (Fig. 1A, D and E).

Within the epididymal region, positivity for TRPV6 $\left(\mathrm{TRPV}^{+}{ }^{+}\right.$) was restricted to the apical membrane of the efferent ductule nonciliated cells (Fig. 2). In the proximal efferent ductules, few TRPV6 ${ }^{+}$cells were detected, contrasting with the distal efferent ductules in which most of nonciliated cells were positive for this protein (Fig. 2A and C). The ciliated cells of the efferent ductules as well as the epithelial cells lining the extratesticular rete testis (not shown) and epididymal duct were not immunoreactive for TRPV6 (Fig. 2E). The immunohistochemical analyses revealed a drastic increase in the frequency of TRPV6 ${ }^{+}$cells in the proximal efferent ductules (Fig. 2B and $\mathrm{H}-$ also, compare Fig. 2A and B), thus confirming the western blotting results. While only

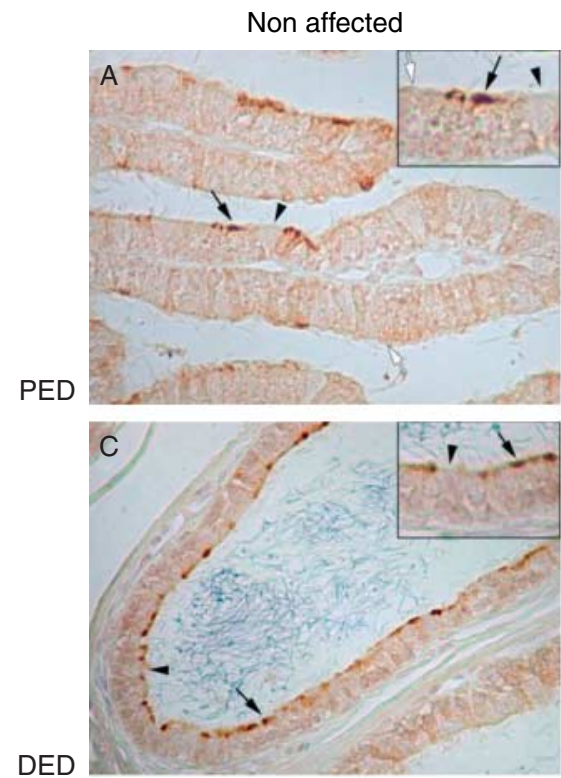

DED
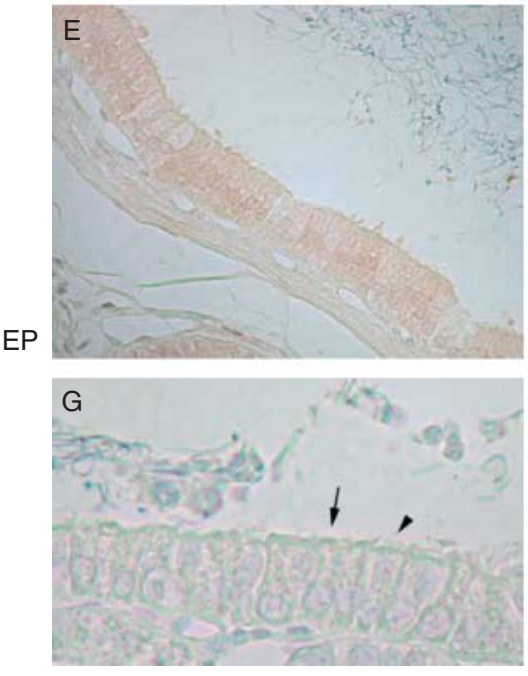
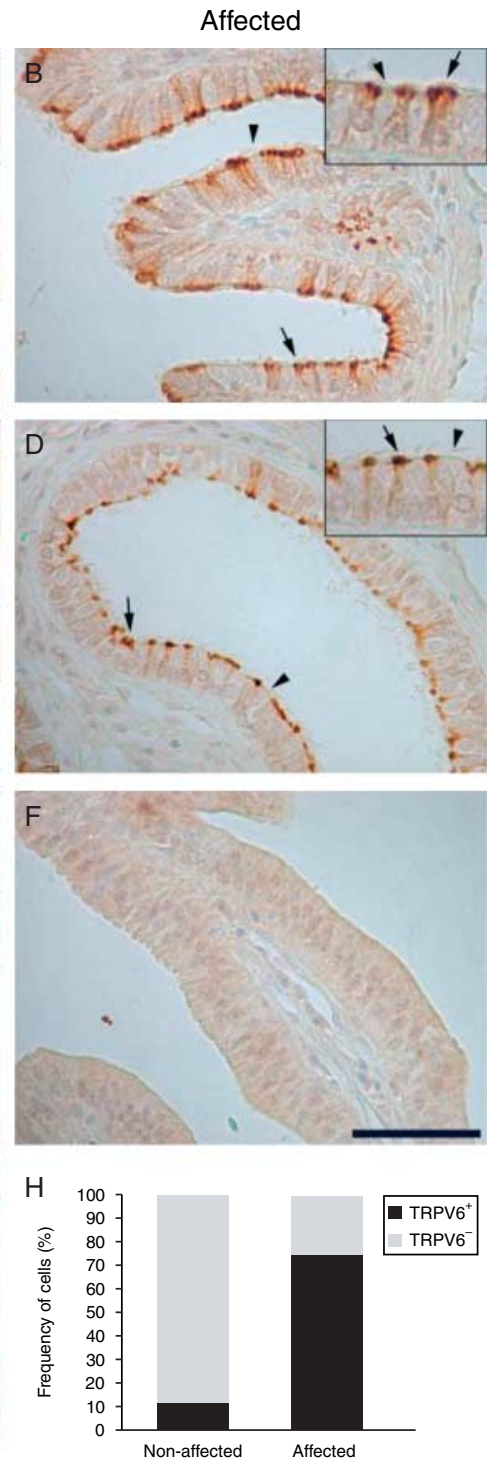

Figure 2 Immunodetection of TRPV 6 in the epididymal region of roosters nonaffected ( $\mathrm{A}, \mathrm{C}$ and $\mathrm{E})$ and affected ( $B, D$ and $F$ ) by epididymal lithiasis. PED, proximal efferent ductules; DED, distal efferent ductules; EP, epididymal duct; black arrows, TRPV6 positive nonciliated cells; white arrows, TRPV6 negative nonciliated cells; arrowheads, ciliated cells; and bar in A, B, C, D, E and F=50 $\mu \mathrm{m}$. Insets in A, B, C and $\mathrm{D}=$ details of the positivity of nonciliated cells and the negative ciliate cells of the efferent ductules. (G) Negative control of the immunostaining highlighting the nonciliated cells (arrow) and ciliated cells (arrowhead). (H) Frequency of TRPV6 positive and negative cells (TRPV $6^{+}$and TRPV $^{-}$respectively) in the proximal efferent ductules of roosters affected and nonaffected by lithiasis. 
about $10 \%$ of the nonciliated cells of the proximal efferent ductules were stained for TRPV6 in nonaffected animals, positivity for this protein was found in $75 \%$ of the nonciliated cells of affected roosters (Fig. $2 \mathrm{H}$ ). No apparent alterations in the pattern of TRPV 6 expression in the rete testis (data not shown), distal efferent ductules, and epididymal duct (compare Fig. 2C with D and Fig. 2E with F).

CaBP-D28K was widely expressed within the epididymal region, as positivity for this protein was found in the cytoplasm of the epithelial cells lining the rete testis (data not shown), efferent ductules, and epididymal duct (Fig. 3). In the efferent ductules, strong positivity for CaBP-D28K was found in the ciliated cells, whereas nonciliated cells were slightly stained (Fig. 3A and C). Within the epididymal duct, positive staining for CaBPD28K was observed in the epithelial principal cells (Fig. 3E). Regarding CaBP-D28K expression, affected roosters showed evident alteration in the pattern of distribution within the epididymal region. In the efferent ductules of these animals, the nonciliated epithelial cells expressed higher levels of CaBP-D28K, both in the proximal and distal regions of these ductules (Fig. 3B and D), when compared to nonaffected animals. No apparent alterations were found in the immunoreaction for this protein in the ciliated cells or in the epithelial cells of other segments comprising the epididymal region (Fig. 3E and F). A noteworthy finding was that a high number of cells comprising mononuclear cell infiltrates, commonly found in the connective tissue of affected animals, were positive for CaBP-D28K (Fig. 3, inset in D).

The expression of NCX1 was restricted to the proximal efferent ductule epithelia (Fig. 4). Among the epithelial cells, positivity was found in the basolateral membrane of some nonciliated cells with an apparent higher concentration of this protein within the basal region (Fig. 4A). The nonciliated cells of the distal efferent ductules and ciliated cells of both segments as well as the epithelia lining the rete testis and epididymal duct were unreactive for NCX1 (Fig. 4A, C and E). This pattern of expression was not altered in roosters affected by epididymal lithiasis (Fig. 4B, D and F).

Considering the alterations in the levels of proteins important for calcium transport across the epithelia in affected animals, Alizarin red staining of epididymal region sections was used to investigate whether calcium could be depositing within the tissue. This histochemical analysis revealed Alizarin red positive granules at the basal region in the nonciliated cells of the affected
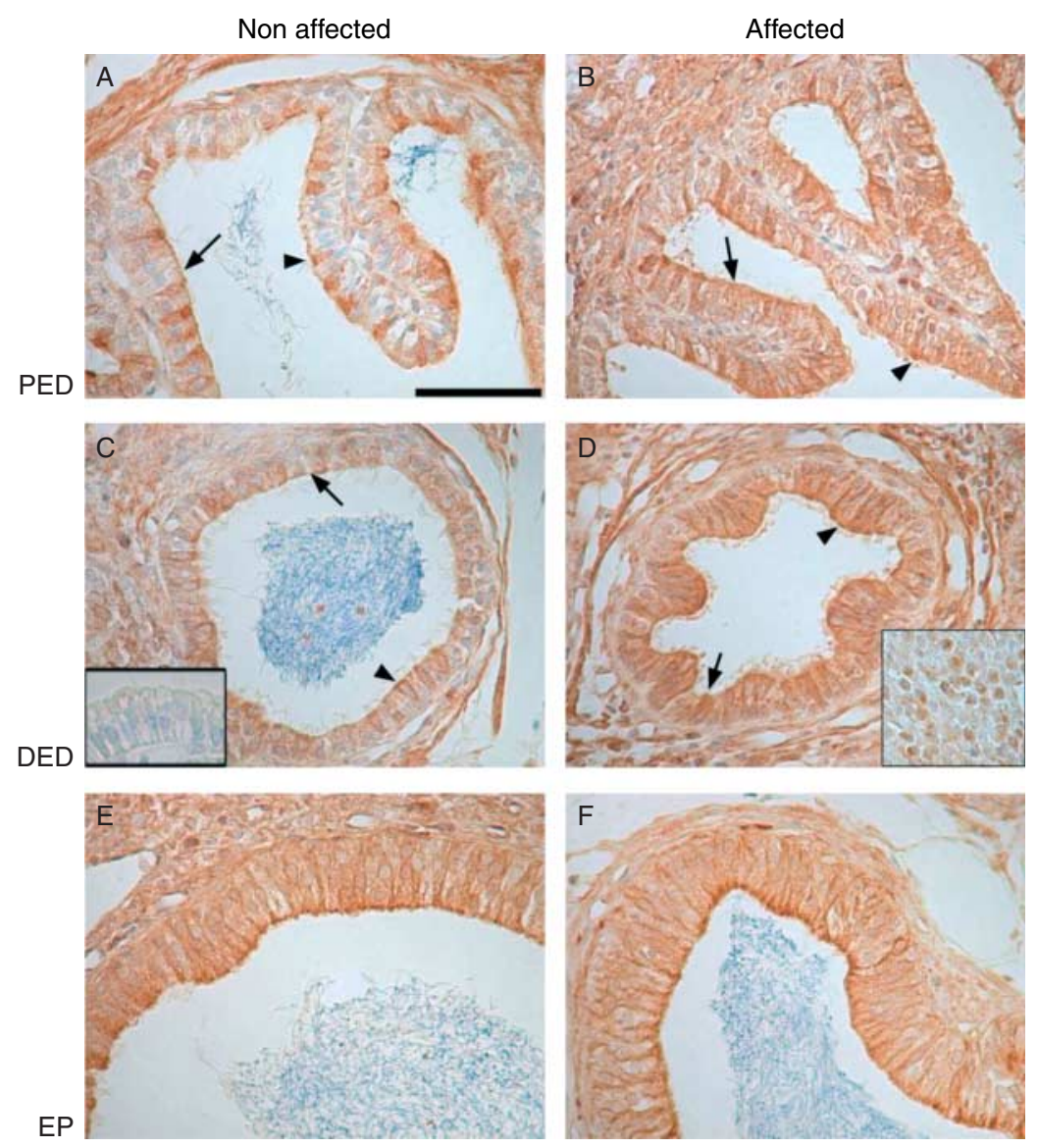

Figure 3 Immunodetection of CaBP-D28K in the epididymal region of roosters nonaffected $(\mathrm{A}, \mathrm{C}$ and E) and affected (B, D and F) by epididymal lithiasis. PED, proximal efferent ductules; DED, distal efferent ductules; EP, epididymal duct; arrows, nonciliated cells; arrowheads, ciliated cells; bar in A, B, C, D, E and $\mathrm{F}=50 \mu \mathrm{m}$. Inset in $\mathrm{C}$, negative control of immunostaining. Inset in D, detail of the positivity of cells within the mononuclear infiltrates. 

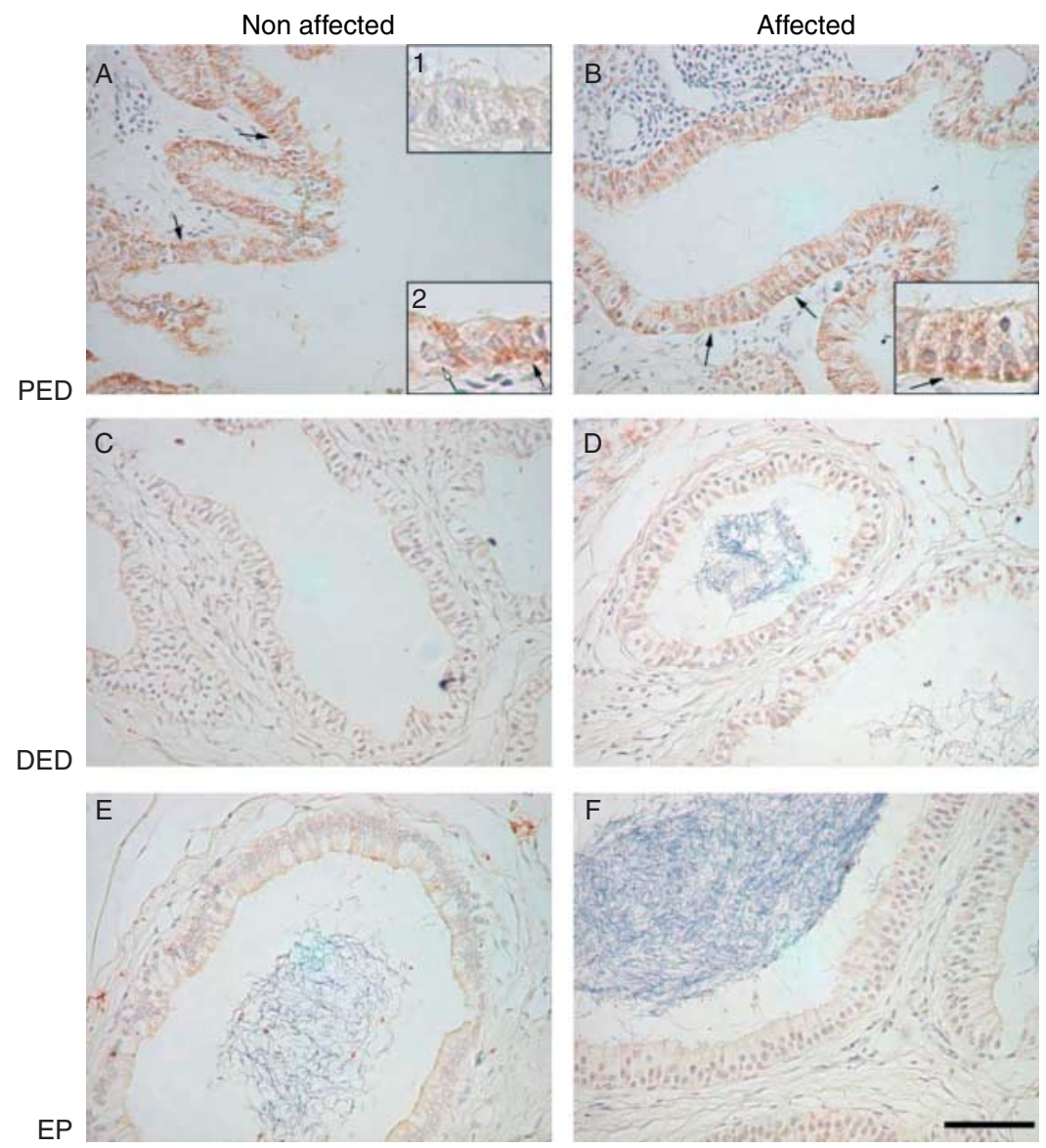

Figure 4 Immunodetection of NCX1 in the epididymal region of roosters nonaffected $(\mathrm{A}, \mathrm{C}$ and $\mathrm{E})$ and affected (B, D and F) by epididymal lithiasis. PED, proximal efferent ductules; DED, distal efferent ductules; EP, epididymal duct; black arrows, NCX1 positive nonciliated cells; white arrows, NCX1 negative nonciliated cells; and bar in A, B, C, D, E and $F=50 \mu \mathrm{m}$. Inset 1 in $A$, negative control of immunostaining; Inset 2 in A and Inset in B, details of the positivity for NCX1 in the nonciliated cells of the proximal efferent ductules. proximal efferent ductules (Fig. 5B), contrasting with the slight stain observed in nonaffected ductules (Fig. 5A). Also, as expected, the luminal calcium stones were strongly stained by Alizarin red (Fig. 5C).

\section{Discussion}

Here, we showed that TRPV6, CaBP-D28K, PMCA, and NCX1 proteins, all of them involved in the transport of calcium across the epithelia, were present in the epididymal region of roosters. Roosters with epididymal lithiasis presented distinct pattern of expression of these proteins, suggesting that an imbalance in calcium homeostasis may be related to the formation of the luminal calcium stones. These are the first findings pointing out a possible molecular mechanism to explain the origin of the epididymal lithiasis, a disorder that drastically decreases the fertility in roosters.

The present study described that the classical proteins involved in calcium reabsorption - TRPV6, CaBP-D28K, PMCA, and NCX1 - are expressed within the epididymal region of roosters, providing, therefore, the putative molecular basis to guarantee calcium homeostasis in the excurrent ducts of birds. Under physiological conditions, it was observed that positivity for TRPV 6 and NCX1 was restricted respectively to the apical and basolateral membrane of the nonciliated cells of the efferent ductules among the ducts comprising the epididymal
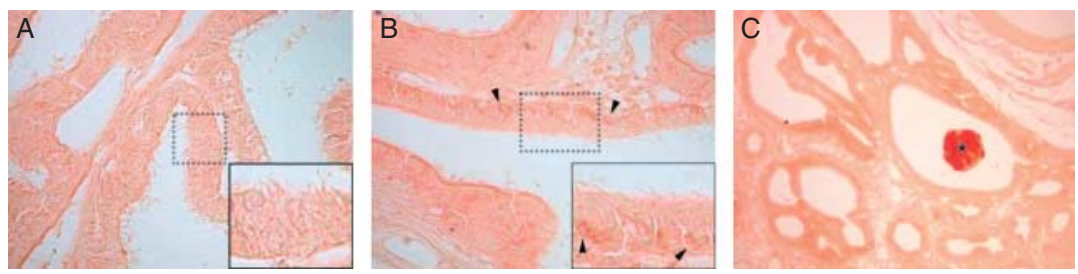

Figure 5 Alizarin red stain of the epididymal region of roosters nonaffected (A) and affected (B) by epididymal lithasis. A positive calcium stone is shown (C). Arrowheads, Alizarin red positive granules; *calcium luminal stone within the efferent ductule. Insets in $A$ and $B$ show the dashed area in higher magnitude and highlights the occurrence and localization of the Alizarin - red positive granules within the basal region of the nonciliated cells of affected animals. 
region. The cytoplasm of these cells was also slightly positive for CaBP-D28K. These results corroborate the finding that the bulk of calcium reabsorption occurs in the efferent ductules (Clulow \& Jones 2004) and reinforces the hypothesis that these cells are the major reabsorptive cells within the efferent ductules of birds (Aire 1980). The maintenance of the correct concentrations of calcium within the luminal fluid in the excurrent ducts is essential for male fertility. In this regard, transgenic male mice that encode TRPV 6 with a mutated pore or that are knocked out for PMCA are infertile due to high concentrations of calcium within the epididymal lumen resulting in impaired capacity of fertilization or in the presence of low motile sperm (Schuh et al. 2004, Weissgerber et al. 2011).

Roosters affected by epididymal lithiasis had increased levels of TRPV6 and CaBP-D28K but not PMCA and NCX1. It is known that modulation of expression of these proteins is under control of different hormones, such as vitamin D3, estrogens, and androgens (Cai et al. 1993, Van Abel et al. 2002, Kip \& Strehler 2004, Hoenderop et al. 2005, Oz et al. 2007, Hsu et al. 2010). On this sense, we showed recently that roosters with lithiasis presented altered levels of vitamin D3, $E_{2}$, and testosterone that paralleled changes in their receptors (VDR, ESR2, and AR respectively) within the epididymal region (Oliveira et al. 2011b). The vitamin D3 and $E_{2}$ responsive systems are directly correlated with TRPV6 and CaBP-D28K expression levels (Hoenderop et al. 2001, 2005, Oz et al. 2007). However, the hormonal effect on the calcium extrusion step is less clear, although it has been shown that vitamin D3 stimulates PMCA expression in the basolateral membranes of reabsorptive cells in the intestine and kidney (Cai et al. 1993, Kip \& Strehler 2004). Recently, it was demonstrated that testosterone inhibits the expression of TRPV5, CaBPD28K, and PMCA (Hsu et al. 2010). Therefore, the hormonal imbalance observed in roosters affected by epididymal lithiasis may be related to the altered pattern of expression of the proteins involved in the transepithelial calcium transport (Oliveira et al. 2011b).

One hypothesis to explain the origin of the epididymal lithiasis was that disruption of local calcium homeostasis would culminate in the formation of the luminal calcium stones (Mahecha et al. 2002, Oliveira \& Oliveira 2011, Oliveira et al. 2011b). The present results corroborate this hypothesis and provide a possible molecular mechanism that could be involved in the origin of such a reproductive disorder (Fig. 6). According to the most accepted model for the calcium transport across the epithelia, calcium enters the cell through specific epithelial calcium channels (TRPV5 or TRPV6), moves throughout the cytoplasm bound to calcium binding proteins (CaBP-D9k or CaBP-D28K), and is extruded to the extracellular medium by the action of a membrane calcium ATPase (PMCA) and/or a NCX1 (Hoenderop et al. 2005). The first steps - calcium entry and diffusion occur following an electrochemical gradient directed from the lumen to the cell cytoplasm and, therefore, are considered as passive steps (den Dekker et al. 2003, Hoenderop et al. 2005). On the other hand, the extrusion step is an active process as it occurs against an electrochemical gradient (Hoenderop et al. 2005). On this sense, based on the fact that only TRPV 6 and
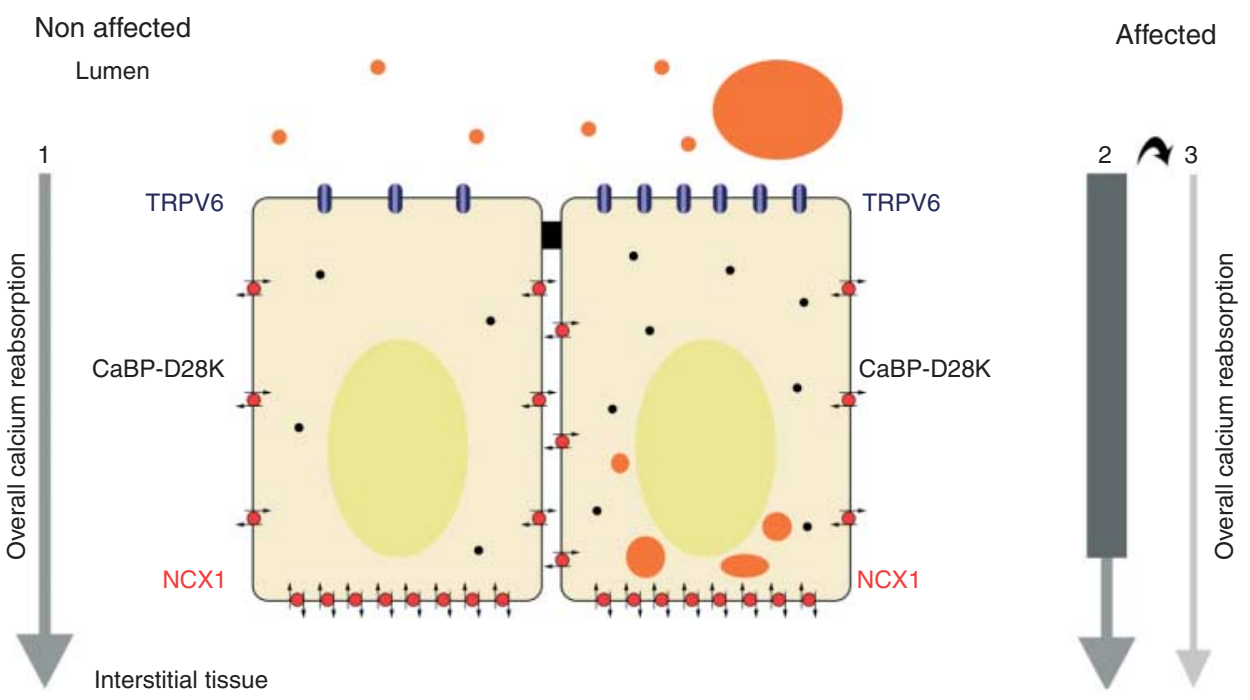

Figure 6 Working hypothesis for luminal calcium stone formation in the efferent ductules of roosters. In roosters nonaffected by epididymal lithiasis (cell on left), normal calcium reabsorption across the proximal efferent ductule epithelium (arrow 1) is mediated by TRPV6, CaBP-D28K, NCX1, and/or PMCA (not shown). Roosters affected by epididymal lithiasis showed higher levels of TRPV6 and CaBP-D28K, but not NCX1 and PMCA proteins. Therefore it is possible that there is an increase in calcium entry within the cell without a parallel increase in its extrusion (arrow 2). This alteration would result in the saturation of the transepithelial calcium transport with consequent decrease in overall calcium reabsorption (arrow 3). This hypothesis is reinforced by the observation of calcium accumulation within the basal region of epithelial cells (orange). Finally, luminal calcium concentrations would be higher in affected animals, serving as nucleating centers for its aggregation into stones. 
CaBP-D28K expression are increased within the epididymal region, it is possible that the calcium transport is saturated, especially considering that the levels of the proteins involved in the extrusion of the ion from the cell do not increase in the same rate. In line with this interpretation is the presence of Alizarin red granules at the basal region of the cells, which suggests the concentration of calcium in this region of the cell. This concentration would result in the dissipation of the inward electrochemical gradient that drives calcium into the cell with the consequent reduction of calcium reabsorption in the efferent ductules (Fig. 6). Finally, calcium is possibly accumulating within the lumen of the efferent ductules and forming nucleating centers to its aggregation into the luminal stones. It is also important to highlight that the overall calcium transepithelial transport may be influenced by other channels, such as $\mathrm{Na}^{+} / \mathrm{K}^{+}$-ATPase, that modulate the steps of this process (Boros et al. 2009). Further investigations regarding other regulatory molecules and channels are needed to fully understand the participation of the calcium reabsorption disruption in the origin/ development of epididymal lithiasis.

The putative local disruption in calcium homeostasis described here may contribute to the pathogenesis of epididymal lithiasis in roosters in different ways. First, it may create favorable conditions for calcium aggregation within the lumen of the efferent ductules as aforementioned, but it can also be associated with other alterations commonly found in the epididymal region of affected animals. It has been shown that elevated intracellular calcium levels may parallel an increase in cell vacuolization in other pathological conditions (Raraty et al. 1999) and, thus, may be a factor that can explain in part the presence of numerous intracellular vacuoles within efferent ductules epithelial cells of roosters with lithiasis (Mahecha et al. 2002). Furthermore, the occurrence of epididymal lithiasis is correlated with decreased daily sperm production and reduced fertility by natural mating (Janssen et al. 2000). Surprisingly, the fertility levels of affected animals are not restored even after the artificial insemination of chickens with equivalent numbers of spermatozoa obtained from semen of affected and nonaffected animals (Janssen et al. 2000). Therefore, the overall reduction in fertility in roosters with lithiasis is likely to be due to alterations in the quality of spermatozoa. In this regard, disruption of local calcium homeostasis leading to increased luminal calcium would affect sperm maturation that occurs in the transit throughout the male extratesticular duct system as similarly described in other models (Schuh et al. 2004, Weissgerber et al. 2011).

Another interesting finding was the strong positivity for CaBP-D28K found in the ciliated cells of the efferent ductules and in the epididymal duct principal cells, both of which were unreactive for the membrane calcium transporters TRPV6 and NCX1. Calbindin-D28K is a protein known to buffer intracellular calcium concentrations but it also serves as a calcium source (Schwaller 2009, 2010). This dual role of calbindins within the cell allows the participation of this protein in other biological processes, such as movement of cilia and secretory function, which may be the case for the efferent ductule ciliated cells and epididymal principal cells respectively (Oz et al. 2007, Schwaller 2009, 2010).

In conclusion, this study provides evidence for the involvement of alterations in the expression of key proteins for calcium reabsorption in the formation of luminal calcium stones within the efferent ductules of roosters. Although it is difficult to separate the cause and consequence relation of the results presently found, the alterations in the calcium handling presented here may be a result of the local hormonal imbalance, such as overexpression of VDR and estrogen/ESR2 and reduction in testosterone, previously demonstrated in the epididymal region of rooster affected by the lithiasis.

\section{Materials and Methods}

\section{Animals and tissue preparation}

The study was performed on the epididymal region of 18 adult crossbred roosters (Gallus gallus), products of unknown breeds, between 1 and 2 years old, in reproductive activity. The animals were obtained from commercial sources and housed at the Universidade Federal de Minas Gerais facilities under natural conditions of light, temperature, and humidity. Water and food (Socil III Guyomarc, Belo Horizonte, Brazil) were administered ad libitum. Food composition is as follows: calcium $(1 \%)$, phosphorous $(0.5 \%)$, other minerals $(7 \%)$, total protein $(13 \%)$, lipids $(2.5 \%)$, fiber $(8 \%)$, and maximum humidity $(13 \%)$. The experimental procedures were approved by the Local Ethical Committee published by the CETEA/UFMG (http://www.ufmg.br/bioetica/coep).

The roosters were weighted, anesthetized (i.p. lethal dose of sodium pentobarbital $50 \mathrm{mg} / \mathrm{kg}$ of body weight) and perfused intracardially with saline and $10 \%$ neutral buffered formalin (NBF) or only with saline solution for immunohistochemical and western blotting analysis respectively.

\section{Diagnostic of epididymal lithiasis}

Epididymal lithiasis was diagnosed by clearing fragments of the epididymal region with potassium hydroxide $(\mathrm{KOH})$ at $0.5 \%$ $(\mathrm{w} / \mathrm{v})$ followed by immersion in glycerin solutions $(1: 2,1: 1$ and pure glycerin) as previously described and validated (Oliveira et al. 2008, 2011b). Animals were classified as affected or nonaffected based on the presence or absence of stones within the epididymal tissue respectively.

\section{Western blotting}

For western blotting assays, fragments of the epididymal region of nonaffected and affected animals ( $n=5$ per group) were 
frozen in liquid nitrogen and macerated with dry ice to address the expression of the proteins of interest: TRPV6, CaBP-D28K, PMCA, and NCX1. We focused on investigating TRPV6 and CaBP-D28K, instead of TRPV5 and CaBP-D9K respectively, because the former have been previously identified in the reproductive system, including bird tissues (den Dekker et al. 2003, Jelinsky et al. 2007, Bar 2008, 2009).

Tissue total protein was extracted by the homogenization of samples with a solution containing 1\% SDS, $30 \mathrm{mM}$ Tris- $\mathrm{HCl}$ ( $\mathrm{pH}$ 6.8), 2-mercaptoethanol, $12 \%$ (v/v) glycerol, and bromophenol blue, as previously described (Oliveira et al. 2008). After total extraction, a total amount of $10 \mu \mathrm{g}$ of proteins were loaded per well for separation by continuous electrophoresis using 10 or $12.5 \%$ SDS-PAGE (for proteins with molecular weight between 140 and $70 \mathrm{kDa}$ or $<50 \mathrm{kDa}$ respectively). To control protein loading, the membranes were probed for $\mathrm{GAPDH}$. Then, the proteins were transferred onto nitrocellulose membranes and nonspecific binding sites in the membranes were blocked by using normal goat serum (NGS) diluted at $10 \%$. The blots were incubated with the primary antibodies rabbit anti-human TRPV6 (Sigma-Aldrich), rabbit anti-rat CaBP-D28K (Sigma-Aldrich), mouse anti-human PMCA (Santa Cruz Biotechnology, Santa Cruz, CA, USA), mouse anti-rabbit NCX1 (Thermo Scientific, Rockford, IL, USA), and rabbit anti-human GAPDH (Cell Signaling, Danvers, MA, USA) diluted at 1:500, 1:200, 1:500, 1:1000, and 1:1000 respectively. Following this step, the membranes were incubated with goat anti-rabbit (for TRPV6, CaBP-D28K, and GAPDH) or goat anti-mouse (for PMCA, NCX1) secondary biotinylated antibodies (Dako, Glostrup, Denmark) at 1:1000 and 1:5000 (for NCX1) and then with the avidin-biotin complex conjugated with peroxidase (Vector Laboratories, Burlingame, CA, USA). After several washes with PBS-Tween $0.05 \%$ and pure PBS, the immunolabeling was visualized with a solution of $0.1 \%(\mathrm{w} / \mathrm{v}) 3,3^{\prime}$-diaminobenzidine in PBS containing $0.05 \%(\mathrm{w} / \mathrm{v})$ chloronaphthol, $16.6 \%(\mathrm{v} / \mathrm{v})$ methanol, and $0.04 \%(\mathrm{v} / \mathrm{v}) \mathrm{H}_{2} \mathrm{O}_{2}$.

\section{Immunohistochemistry}

NBF fixed fragments of the epididymal region of roosters affected and nonaffected by epididymal lithiasis were embedded in paraffin, sectioned at $5.0 \mu \mathrm{m}$, and used for immunohistochemical analysis. The technique was performed in duplicates and, for comparison between animals and groups, the staining was run in parallel. After endogenous peroxidase activity blocking with $0.6 \%(\mathrm{v} / \mathrm{v}) \mathrm{H}_{2} \mathrm{O}_{2}$ in methanol, sections were submitted to standard protocol of antigen retrieval in $0.01 \mathrm{M}$ sodium citrate buffer $(\mathrm{pH}$ 6.0) and microwave heating. Nonspecific binding was blocked by incubation of the sections with avidin and biotin blocking kit (Vector Laboratories) and $10 \%$ NGS. The slides were incubated with the primary rabbit anti-human TRPV6 (Sigma-Aldrich), rabbit anti-rat CaBPD28K (Sigma-Aldrich), and mouse anti-rabbit NCX1 (Thermo Scientific) antibodies at the dilution of 1:500, 1:200, and 1:100 respectively. Then, sections were incubated with goat antirabbit (for TRPV6 and CaBP-D28K) and goat anti-mouse (for NCX1) secondary biotinylated antibodies (Dako) diluted at 1:100 and then with the avidin-biotin complex conjugated with peroxidase (Vector Laboratories). Negative controls were obtained by omitting the primary antibodies and incubation with the appropriate anti-lgG. The reaction was visualized by immersion in $0.05 \% \quad 3,3^{\prime}$-diaminobenzidine solution containing $0.01 \% \mathrm{H}_{2} \mathrm{O}_{2}$ in $0.05 \mathrm{M}$ Tris- $\mathrm{HCl}$ buffer ( $\mathrm{pH} 7.4$ ). Finally, the sections were counterstained with hematoxylin, dehydrated, washed in xylene and mounted.

\section{Quantitative studies}

The comparison of TRPV6, CaBP-D28K, NCX1, and PMCA expression between nonaffected and affected roosters were quantified in western blotting membranes. For this purpose, the specific protein bands were traced and measured with a constant measurement area around the bands. Background intensity was determined by tracing an unlabeled area adjacent to the measured band. The final intensity was determined by subtracting background intensity from positive values for each band (Oliveira et al. 2007).

The frequency of TRPV 6 positive cells within the epididymal region was determined in the immunohistochemical slides, according to the literature (Oliveira et al. 2006). For this purpose, it was counted the immunoreactive cells per 100 epithelial nonciliated cells in ten randomly selected longitudinal sections of the proximal efferent ductules.

\section{Alizarin red stain}

To investigate the occurrence of possible calcium deposits within the epididymal region, $5 \mu \mathrm{m}$ sections of NBF fixed tissues were incubated with Alizarin red stain for $3 \mathrm{~min}$. The Alizarin red interaction with calcium results in an orange/red product that can be visualized under the microscope (McGee-Russell 1958, Mori et al. 2000).

\section{Statistical analysis}

Data about the expression of TRPV6, CaBP-D28K, PMCA, and NCX1 as well as the frequency of TRPV 6 positive cells in the epididymal region of roosters nonaffected and affected by epididymal lithiasis were statistically analyzed to detect possible differences between groups. For this purpose, the normal distribution of the data and the homogeneity of variances were tested prior to the realization of the Student's $t$-test. Differences were considered significant at $P \leq 0.05$.

\section{Declaration of interest}

The authors declare that there is no conflict of interest that could be perceived as prejudicing the impartiality of the research reported.

\section{Funding}

This work was supported by the Fundação de Amparo à Pesquisa do Estado de Minas Gerais - FAPEMIG/Brazil (grant numbers AQP-4712-3.13/07 and CBB-723/6 to C A Oliveira; scholarship to D J Q Aquino) and the Conselho Nacional de 
Desenvolvimento Científico e Tecnológico - CNPq/Brazil (research fellowship to C A Oliveira, doctoral fellowship to A G Oliveira and technician fellowship).

\section{Acknowledgements}

Authors thank the technical assistance of Elisângela Martins dos Santos and Júnia Dayrell de Moura Cordeiro.

\section{References}

Aire TA 1979a The epididymal region of the Japanese quail (Coturnix coturnix japonica). Acta Anatomica 103 305-312. (doi:10.1159/ 000145028)

Aire TA $1979 b$ Micro-stereological study of the avian epididymal region. Journal of Anatomy 129 703-706.

Aire TA 1980 The ductuli efferentes of the epididymal region of birds. Journal of Anatomy 130 707-723.

Aire TA 2000 Aspects of the functional morphology of the ductus epididymidis in domestic anseriform and galliform birds. Anatomia, Histologia, Embryologia 29 179-191. (doi:10.1046/j.1439-0264.2000. 00259.x)

Bar A 2008 Calcium homeostasis and vitamin D metabolism and expression in strongly calcifying laying birds. Comparative Biochemistry and Physiology. Part A, Molecular \& Integrative Physiology 151 477-490. (doi:10.1016/j.cbpa.2008.07.006)

Bar A 2009 Calcium transport in strongly calcifying laying birds: mechanisms and regulation. Comparative Biochemistry and Physiology. Part A, Molecular \& Integrative Physiology 152 447-469. (doi:10.1016/j. cbpa.2008.11.020)

Bindels RJ, Hartog A, Timmermans J \& Van Os CH 1991 Active $\mathrm{Ca}^{2+}$ transport in primary cultures of rabbit kidney CCD: stimulation by $1,25-$ dihydroxyvitamin D3 and PTH. American Journal of Physiology 261 F799-F807.

Boltz DA, Nakai M \& Bahra JM 2004 Avian infectious bronchitis virus: a possible cause of reduced fertility in the rooster. Avian Diseases $\mathbf{4 8}$ 909-915. (doi:10.1637/7192-040808R1)

Boltz DA, Zimmerman CR, Nakai M, Bunick D, Scherba G \& Bahr JM 2006 Epididymal stone formation and decreased sperm production in roosters vaccinated with a killed strain of avian infectious bronchitis virus. Avian Diseases 50 594-598. (doi:10.1637/7654-052506R.1)

Boros S, Bindels RJ \& Hoenderop JG 2009 Active $\mathrm{Ca}(2+)$ reabsorption in the connecting tubule. Pflügers Archiv: European Journal of Physiology 458 99-109. (doi:10.1007/s00424-008-0602-6)

Cai Q, Chandler JS, Wasserman RH, Kumar R \& Penniston JT 1993 Vitamin $\mathrm{D}$ and adaptation to dietary calcium and phosphate deficiencies increase intestinal plasma membrane calcium pump gene expression. PNAS 90 1345-1349. (doi:10.1073/pnas.90.4.1345)

Clulow J \& Jones RC 1988 Studies of fluid and spermatozoal transport in the extratesticular genital ducts of the Japanese quail. Journal of Anatomy $1571-11$.

Clulow J \& Jones RC 2004 Composition of luminal fluid secreted by the seminiferous tubules and after reabsorption by the extratesticular ducts of the Japanese quail, Coturnix coturnix japonica. Biology of Reproduction 71 1508-1516. (doi:10.1095/biolreprod.104.031401)

den Dekker E, Hoenderop JG, Nilius B \& Bindels RJ 2003 The epithelial calcium channels, TRPV5 \& TRPV6: from identification towards regulation. Cell Calcium 33 497-507. (doi:10.1016/S0143-4160(03)00065-4)

Dick IM, Liu J, Glendenning P \& Prince RL 2003 Estrogen and androgen regulation of plasma membrane calcium pump activity in immortalized distal tubule kidney cells. Molecular and Cellular Endocrinology 212 11-18. (doi:10.1016/j.mce.2003.09.028)

Dornas RA, Oliveira AG, Kalapothakis E, Hess RA, Mahecha GA \& Oliveira CA 2007 Distribution of vitamin D3 receptor in the epididymal region of roosters (Gallus domesticus) is cell and segment specific. General and Comparative Endocrinology 150 414-418. (doi:10.1016/j. ygcen.2006.10.010)

Dornas RA, Oliveira AG, Dias MO, Mahecha GA \& Oliveira CA 2008 Comparative expression of androgen receptor in the testis and epididymal region of roosters (Gallus domesticus) and drakes (Anas platyrhynchos). General and Comparative Endocrinology 155 773-779. (doi:10.1016/j.ygcen.2007.08.010)

Hoenderop JG, Muller D, Van Der Kemp AW, Hartog A, Suzuki M, Ishibashi K, Imai M, Sweep F, Willems PH, Van Os CH et al. 2001 Calcitriol controls the epithelial calcium channel in kidney. Journal of the American Society of Nephrology 12 1342-1349.

Hoenderop JG, Nilius B \& Bindels RJEC 2002 CaC: the gatekeeper of transepithelial $\mathrm{Ca}^{2+}$ transport. Biochimica et Biophysica Acta $\mathbf{1 6 0 0}$ 6-11. (doi: 10.1016/S1570-9639(02)00438-7)

Hoenderop JG, Nilius B \& Bindels RJ 2005 Calcium absorption across epithelia. Physiological Reviews 85 373-422. (doi:10.1152/physrev. 00003.2004)

Hsu YJ, Dimke H, Schoeber JP, Hsu SC, Lin SH, Chu P, Hoenderop JG \& Bindels RJ 2010 Testosterone increases urinary calcium excretion and inhibits expression of renal calcium transport proteins. Kidney International 77 601-608. (doi:10.1038/ki.2009.522)

Jackson UH, Boltz DA, Nakai M, Scherba G, Bunick D \& Bahr J 2006 Prepubertal exposure to the live attenuated avian infectious bronchitis virus induces epididymal stones in the rooster after puberty. Journal of Poultry Science 43 280-285. (doi:10.2141/jpsa.43.280)

Janssen SJ, Kirby JD, Hess RA, Rhoads M, Bunick D, Bailey KL, Parsons CM, Wang H \& Bahr JM 2000 Identification of epididymal stones in diverse rooster populations. Poultry Science 79 568-574.

Jelinsky SA, Turner TT, Bang HJ, Finger JN, Solarz MK, Wilson E, Brown EL, Kopf GS \& Johnston DS 2007 The rat epididymal transcriptome: comparison of segmental gene expression in the rat and mouse epididymides. Biology of Reproduction 76 561-570. (doi:10.1095/ biolreprod.106.057323)

Kennedy BG, Torabi AJ, Kurzawa R, Echtenkamp SF \& Mangini NJ 2010 Expression of transient receptor potential vanilloid channels TRPV5 and TRPV6 in retinal pigment epithelium. Molecular Vision 16 665-675.

King AS. Aves: urogenital system. In The Anatomy of Domestic Animals, pp 1919-1964. Eds R Getty. Philadelphia: WB Saunders Company, 1975.

Kip SN \& Strehler EE 2004 Vitamin D3 upregulates plasma membrane $\mathrm{Ca}^{2+}$-ATPase expression and potentiates apico-basal $\mathrm{Ca}^{2+}$ flux in MDCK cells. American Journal of Physiology. Renal Physiology 286 F363-F369. (doi:10.1152/ajprenal.00076.2003)

Kwon S, Hess RA, Bunick D, Kirby JD \& Bahr JM 1997 Estrogen receptors are present in the epididymis of the rooster. Journal of Andrology $\mathbf{1 8}$ 378-384.

Mahecha GA, Oliveira CA, Balzuweit K \& Hess RA 2002 Epididymal lithiasis in roosters and efferent ductule and testicular damage. Reproduction 124 821-834. (doi:10.1530/rep.0.1240821)

McGee-Russell SM 1958 Histochemical methods for calcium. Journal of Histochemistry and Cytochemistry 6 22-42. (doi:10.1177/6.1.22)

Meyer MB, Zella LA, Nerenz RD \& Pike JW 2007 Characterizing early events associated with the activation of target genes by 1,25-dihydroxyvitamin D3 in mouse kidney and intestine in vivo. Journal of Biological Chemistry 282 22344-22352. (doi:10.1074/jbc.M703475200)

Mori F, Tanji K \& Wakabayashi K 2000 Widespread calcium deposits, as detected using the alizarin red $\mathrm{S}$ technique, in the nervous system of rats treated with dimethyl mercury. Neuropathology 20 210-215. (doi:10.1046/j.1440-1789.2000.00341.x)

Oliveira AG \& Oliveira CA 2011 Epididymal lithiasis in roosters: in the middle of the way there was a stone. Life Sciences 89 588-594. (doi:10. 1016/j.Ifs.2011.04.021)

Oliveira CA, Telles LF, Oliveira AG, Kalapothakis E, Goncalves-Dornelas H \& Mahecha GA 2006 Expression of different classes of immunoglobulin in intraepithelial plasma cells of the Harderian gland of domestic ducks Anas platyrhynchos. Veterinary Immunology and Immunopathology $\mathbf{1 1 3}$ 257-266. (doi:10.1016/j.vetimm.2006.05.008)

Oliveira AG, Coelho PH, Guedes FD, Mahecha GA, Hess RA \& Oliveira CA 2007 5alpha-Androstane-3beta,17beta-diol (3beta-diol), an estrogenic metabolite of 5alpha-dihydrotestosterone, is a potent modulator of estrogen receptor ERbeta expression in the ventral prostrate of adult rats. Steroids 72 914-922. (doi:10.1016/j.steroids.2007.08.001)

Oliveira AG, Dornas RA, Kalapothakis E, Hess RA, Mahecha GA \& Oliveira CA 2008 Vitamin D3 and androgen receptors in testis and epididymal region of roosters (Gallus domesticus) as affected by epididymal lithiasis. Animal Reproduction Science 109 343-355. (doi:10.1016/j.anireprosci.2007.11.009) 
Oliveira AG, Dornas RA, Mahecha GA \& Oliveira CA 2011 a Occurrence and cellular distribution of estrogen receptors ERalpha and ERbeta in the testis and epididymal region of roosters. General and Comparative Endocrinology 170 597-603. (doi:10.1016/j.ygcen.2010.11.016)

Oliveira AG, Dornas RA, Praes LC, Hess RA, Mahecha GA \& Oliveira CA $2011 b$ Roosters affected by epididymal lithiasis present local alteration in vitamin D3, testosterone and estradiol levels as well as estrogen receptor 2 (beta) expression. Reproduction 142 439-446. (doi:10.1530/REP-11-0131)

Oz OK, Hajibeigi A, Howard K, Cummins CL, van Abel M, Bindels RJ, Word RA, Kuro-o M, Pak CY \& Zerwekh JE 2007 Aromatase deficiency causes altered expression of molecules critical for calcium reabsorption in the kidneys of female mice*. Journal of Bone and Mineral Research 22 1893-1902. (doi:10.1359/jbmr.070808)

Raraty MG, Petersen OH, Sutton R \& Neoptolemos JP 1999 Intracellular free ionized calcium in the pathogenesis of acute pancreatitis. Baillière's Best Practice Research. Clinical Gastroenterology 13 241-251. (doi:10.1053/ bega.1999.0022)

Schuh K, Cartwright EJ, Jankevics E, Bundschu K, Liebermann J, Williams JC, Armesilla AL, Emerson M, Oceandy D, Knobeloch KP et al. 2004 Plasma membrane $\mathrm{Ca}^{2+}$ ATPase 4 is required for sperm motility and male fertility. Journal of Biological Chemistry 279 28220-28226. (doi:10.1074/ jbc.M312599200)

Schwaller B 2009 The continuing disappearance of 'pure' $\mathrm{Ca}^{2+}$ buffers. Cellular and Molecular Life Sciences 66 275-300. (doi:10.1007/s00018008-8564-6)

Schwaller B 2010 Cytosolic $\mathrm{Ca}^{2+}$ buffers. Cold Spring Harbor Perspectives in Biology 2 a004051. (doi:10.1101/cshperspect.a004051)

Suzuki Y, Landowski CP \& Hediger MA 2008 Mechanisms and regulation of epithelial $\mathrm{Ca}^{2+}$ absorption in health and disease. Annual Review of Physiology 70 257-271. (doi:10.1146/annurev.physiol.69.031905.161003) de Talamoni N, Smith CA, Wasserman RH, Beltramino C, Fullmer CS \& Penniston JT 1993 Immunocytochemical localization of the plasma membrane calcium pump, calbindin-D28k, and parvalbumin in Purkinje cells of avian and mammalian cerebellum. PNAS 90 11949-11953. (doi:10.1073/pnas.90.24.11949)

Van Abel M, Hoenderop JG, Dardenne O, St Arnaud R, Van Os CH, Van Leeuwen HJ \& Bindels RJ 2002 1,25-Dihydroxyvitamin D(3)-independent stimulatory effect of estrogen on the expression of ECaC1 in the kidney. Journal of the American Society of Nephrology 13 2102-2109. (doi:10.1097/01.ASN.0000022423.34922.2A)

Van Baal J, Yu A, Hartog A, Fransen JA, Willems PH, Lytton J \& Bindels RJ 1996 Localization and regulation by vitamin D of calcium transport proteins in rabbit cortical collecting system. American Journal of Physiology 271 F985-F993.

Weissgerber P, Kriebs U, Tsvilovskyy V, Olausson J, Kretz O, Stoerger C, Vennekens R, Wissenbach U, Middendorff R, Flockerzi V et al. 2011 Male fertility depends on $\mathrm{Ca}(2)+$ absorption by TRPV 6 in epididymal epithelia. Science Signaling 4 ra27. (doi:10.1126/scisignal.2001791)

Yang H, Choi KC, Hyun SH \& Jeung EB 2011 Coexpression and estrogenmediated regulation of TRPV 6 and PMCA1 in the human endometrium during the menstrual cycle. Molecular Reproduction and Development 78 274-282. (doi:10.1002/mrd.21303)

Received 25 January 2012

First decision 21 February 2012

Accepted 19 March 2012 